\title{
FIRST OCCURRENCE OF Xylosandrus germanus (Blandford, 1894) - BLACK STEAM BORER IN PHEROMONE BAITED PANEL TRAPS AND POPULATION BUILD UP IN CROATIAN OAK STANDS
}

\author{
PRVI ULOVI Xylosandrus germanus (Blandford, 1894) \\ U NALETNO-BARIJERNIM KLOPKAMA I PORAST POPULACIJE \\ U NIZINSKIM HRASTOVIM SASTOJINAMA HRVATSKE
}

Milivoj FRANJEVIĆ ${ }^{\text {, Zoran ŠIKIĆ }}{ }^{2}$, Boris HRAŠOVEC ${ }^{3}$

\begin{abstract}
SUMMARY
During the first decade of 21st century in Croatian oak stands series of experiments concerning integrated oak timber protection were conducted. In the focus of this research was olfactory manipulation with native ambrosia beetles from genus Trypodendron and Xyleborus. Pheromone baited panel traps were used completed with different attractive components (lineatin, ETOH, GLV, Domowit-Trypowit $\mathrm{D}^{\circ}$ ). During these experiments in trap catches new species of scolityd for Croatian lowland oak stands entomofauna was discovered. Occurrence of XYlosandrus germanus was first time registered in a second season of field experiments and its numbers had since continuously grown in trap catches. In 2011. monitoring of flight period for ambrosia beetles was conducted from beginning of January till early June. During this period six species of ambrosia beetles were caught among them most numerous species was T. signatum while X. germanus was second although only present in trap catches for four years.
\end{abstract}

KEY WORDS: ambrosia bark beetles, integrated oak timber protection, CEN EN 1316-1, FSC certified forests, invasive alien species

\section{INTRODUCTION}

\section{UVOD}

Invasive species of insects represent challenge for forest protection in conditions of managed FSC certified forests in which use of insecticides is restricted. Croatian forests are about $90 \%$ state owned and are FSC certified. In oak stands in Croatia ambrosia beetles are important economical pests that degrade value of round oak timber that is exposed to these beetles during winter harvesting (Franjevic et al,2016) Most important species are from genus Trypodendron and Xyleborus. Earliest species to invade exposed oak timber are Trypodendron domesticum (Linnaeus, 1758) and Trypodendron signatum (Fabricius, 1792) which swarm in late January and early February. In mid spring these are followed

\footnotetext{
${ }^{1}$ Assistant professor Franjević Milivoj (milivoj.franjevic@sumfak.hr), University of Zagreb, Svetošimunska cesta 23, 10002 Zagreb

2 Assistant professor Zoran Šikić (zsikic@unizd.hr), University of Zadar, Department for Ecology, Agronomy and Aquaculture Trg kneza Višeslava 9, 23000 Zadar

${ }^{3}$ Professor Boris Hrašovec (hrasovec@sumfak.hr), University of Zagreb, Svetošimunska cesta 23, 10002 Zagreb
} 
by Xyleborus saxesenii (Ratzeburg, 1837), Xyleborus dispar (Fabricius, 1792), Xyleborus monographus (Fabricius, 1792). European norm for round oak timber EN 1316-1 is strict in regard of damage from beetles and in two highest classes Q-A and Q-B do not allow any beetle holes. Beetle holes in quality grade Q-C are accepted only in sapwood, and in lowest grade Q-D are accepted (FprEN 1316-1:2012:2012: E). From economical point of view this means that round oak timber can in short time sometimes if swarming is strong a matter of days loose $60 \%$ of its commercial value. It sometimes means loss of about $200 €$ per $1 \mathrm{~m}^{3}$. All this emphasize importance of oak timber protection from our native and invasive ambrosia bark beetles. During period of our experiments we recorded in our panel traps presence of $X$. germanus invasive ambrosia beetle. Today it is abundant species although it was not registered in similar monitoring experiments before 2009 (Jendrijev 2005). X. germanus is Asian species first time described in Germany in 1951 near Darmstadt. In next decade it had spread and is viewed as potential primary pest (Gauss 1960). This paper presents dynamics of $X$. germanus in oak lowland stands during period of integrated oak timber protection research from 2003, its first occurrence in catches 2009 till 2011 near Zagreb Croatia.

\section{MATERIAL AND METHODS} MATERIJALI I METODE

In lowland oak stands methods of integrated oak timber protection were tested during period from 2003 to 2011. In that period pheromone baited panel traps were used for purpose of olfactory manipulation, trapping and monitoring of ambrosia beetle phenology. IPM" Tech Intercept ${ }^{\mathrm{TM}}$ panel traps were used because of their advanteges over Lindgren and Theysohn panel traps in Cerambycid and Scolytid trapping. IPM ${ }^{\circ}$ Tech Intercept ${ }^{\mathrm{TM}}$ panel traps catch beetles from all four quadrants and are less susceptible to weather conditions and predatory entomofauna which can influence results of trapping (Czokajlo et al. 2002). Also because of different strategies that were used in oak timber protection from ambrosia beetles traps were not always ac- tive at same time of year. Use of panel traps and their efficiency was tested in different vegetation periods. Nevertheless they were always active in period when we can expect $X$. germanus swarming. IPM ${ }^{\circ}$ Tech Intercept ${ }^{\mathrm{TM}}$ were completed with different attractive components in years of experiment. In 2003. panel traps were completed with lineatin that is known attractive component for ambrosia beetles (MacConell et al. 1977). In year 2009. for trapping in panel traps ETOH, GLV (Green leaf volatile) and Domowit-Trypowit $\mathrm{D}^{\circ}$ was used. Same attractive components were used in 2010. and 2011. ETOH is known attractant for ambrosia beetles (Moeck 1970) and Domowit-Trypowit $\mathrm{D}^{\circ}$ is commercially available product for trapping of beetles from Trypodendron genus. In year 2011 monitoring of ambrosia beetle phenology was conducted from early January till early June in that time Spectrum Technologies Inc. Watchdog Weather Station 2000 Series was used for logging of temperature. Data from traps and weather station was used for purpose of establishing correlation between phenology (E.g. min. and max weekly temperature) and species occurrence. Throughout duration of these experiments panel trap catches were collected weekly and analyzed in laboratory.

\section{RESULTS AND DISCUSSION REZULTATI I RASPRAVA}

During period of trapping in 2003. 30 panel traps didn't catch single specimen of X. germanus. In that year dominant species was T. signatum and T. domesticum (Table 1.)

Period of trapping in 2009. was the first time that X. germanus was caught in panel traps baited with ETOH, GLV and

Table 1. Ambrosia beetle catches in 2003. on lineatin baited traps. Tablica 1. Ulovi potkornjaka drvaša 2003. godine u klopkama s lineatinom

\begin{tabular}{lcccccc}
\multicolumn{1}{c}{2003} & 04.3. & 11.3. & 24.3. & 27.3. & 02.4. & $\sum$ \\
Trypodendron signatum & 86 & 813 & 465 & 228 & 304 & 1896 \\
Trypodendron domesticum & 325 & 1107 & 231 & 79 & 85 & 1827 \\
Xyleborus dispar & 0 & 0 & 0 & 14 & 31 & 45 \\
Xyleborus saxesenii & 0 & 0 & 4 & 151 & 208 & 363 \\
\multicolumn{1}{c}{$\sum$} & 411 & 1920 & 700 & 472 & 628 & 4131
\end{tabular}

Table 2. Ambrosia beetle catches in 2009. on ETOH, GLV and Domowit-Trypowit $\mathrm{D}^{\circledR}$ baited traps. Tablica 2. Ulovi potkornjaka drvaša 2009. godine u klopkama s ETOH, GLV i Domowit-Trypowit D ${ }^{\circledR}$

\begin{tabular}{lcccccccc}
\multicolumn{1}{c}{2009} & 17.03. & 24.3. & 31.03. & 07.04 & 14.04. & 21.04. & 28.04. & $\sum$ \\
Trypodendron domesticum & 1 & 2 & 0 & 2 & 1 & 4 & 7 & 17 \\
Trypodendron signatum & 3563 & 660 & 575 & 849 & 1238 & 1168 & 1172 & 9225 \\
Xyleborus saxesenii & 20 & 1 & 41 & 432 & 87 & 21 & 5 & 607 \\
Xyleborus dispar & 0 & 0 & 0 & 83 & 78 & 22 & 10 & 193 \\
Xyleborus monographus & 0 & 0 & 0 & 0 & 155 & 239 & 49 & 443 \\
Xylosandrus germanus & 0 & 0 & 0 & 6 & 195 & 100 & 62 & 363 \\
Taphrorychus bicolor & 0 & 0 & 0 & 4 & 0 & 0 & 0 & 4 \\
\multicolumn{1}{c}{$\Sigma$} & 3584 & 663 & 616 & 1376 & 1754 & 1554 & 1305 & 10852
\end{tabular}


Table 3. Ambrosia beetle catches in 2010. on ETOH, GLV and Domowit-Trypowit $\mathrm{D}^{\circledR}$ baited traps.

Tablica 3. Ulovi potkornjaka drvaša 2010. godine u klopkama s ETOH, GLV i Domowit-Trypowit D ${ }^{\circledR}$

\begin{tabular}{|c|c|c|c|c|c|c|c|}
\hline 2010 & 21.04 & 27.4 & 5.5. & 12.05. & 19.05. & 26.05. & $\Sigma$ \\
\hline X. signatum & 537 & 526 & 546 & 399 & 107 & 212 & 2327 \\
\hline X. domesticum & 3 & 0 & 6 & 5 & 6 & 9 & 29 \\
\hline X. dispar & 31 & 6 & 8 & 5 & 1 & 12 & 63 \\
\hline X. germanus & 70 & 73 & 283 & 98 & 19 & 317 & 860 \\
\hline X. saxesenii & 60 & 44 & 58 & 8 & 5 & 23 & 198 \\
\hline X. monographus & 9 & 161 & 177 & 22 & 5 & 53 & 427 \\
\hline$\sum$ & 710 & 810 & 1078 & 537 & 143 & 626 & 3904 \\
\hline
\end{tabular}

Table 4. Ambrosia beetle catches in 2011. with ETOH Domowit-Trypowit $D^{\circledR}$ baited traps.

Tablica 4. Ulovi potkornjaka drvaša 2011. godine u klopkama s ETOH, GLV i Domowit-Trypowit D ${ }^{\circledR}$

\begin{tabular}{|c|c|c|c|c|c|c|c|c|c|c|c|c|c|c|c|c|c|c|c|c|c|c|}
\hline 2011 & $\begin{array}{l}\dot{\circ} \\
\infty \\
\infty\end{array}$ & $\begin{array}{l}\dot{\delta} \\
\dot{\alpha}\end{array}$ & $\frac{\dot{d}}{\dot{\sigma}}$ & $\begin{array}{l}\text { ㅇ } \\
\text { o }\end{array}$ & $\begin{array}{l}\text { ญ் } \\
\text { ำ }\end{array}$ & $\begin{array}{l}\stackrel{\delta}{\delta} \\
\underset{N}{N}\end{array}$ & $\frac{⿱ 亠 凶}{\sigma}$ & $\begin{array}{l}\text { ஜ̊ } \\
\text { o }\end{array}$ & $\begin{array}{l}\text { ஜे } \\
\stackrel{2}{2}\end{array}$ & $\begin{array}{l}\ddot{O} \\
\underset{N}{N}\end{array}$ & $\begin{array}{l}\text { oे } \\
\text { Dे }\end{array}$ & $\begin{array}{l}\dot{0} \\
\text { ํㅇ }\end{array}$ & 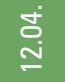 & $\begin{array}{l}\dot{O} \\
\stackrel{0}{-}\end{array}$ & $\begin{array}{l}\text { ठ் } \\
\stackrel{d}{0}\end{array}$ & $\begin{array}{l}\text { 호 } \\
\text { ஜ் }\end{array}$ & $\begin{array}{l}\text { 롱 } \\
\stackrel{0}{0}\end{array}$ & $\stackrel{\text { 농 }}{=}$ & 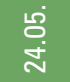 & $\frac{\operatorname{sic}}{\frac{0}{m}}$ & $\begin{array}{l}\dot{8} \\
\tilde{\delta}\end{array}$ & $\Sigma$ \\
\hline T. domesticum & 171 & 7 & 0 & 99 & 226 & 1 & 0 & 0 & 317 & 55 & 59 & 27 & 26 & 10 & 46 & 36 & 82 & 110 & 53 & 23 & 8 & 1356 \\
\hline T. signatum & 1 & 0 & 0 & 84 & 352 & 0 & 0 & 0 & 2317 & 351 & 1609 & 856 & 878 & 570 & 2105 & 872 & 1245 & 1615 & 1103 & 540 & 289 & 14787 \\
\hline X. saxesenii & 0 & 0 & 0 & 0 & 0 & 0 & 0 & 0 & 3 & 41 & 62 & 189 & 44 & 5 & 24 & 1 & 7 & 87 & 135 & 94 & 31 & 723 \\
\hline X. dispar & 0 & 0 & 0 & 0 & 0 & 0 & 0 & 0 & 0 & 0 & 35 & 39 & 11 & 2 & 5 & 0 & 5 & 12 & 2 & 3 & 2 & 116 \\
\hline X. monographus & 0 & 0 & 0 & 0 & 0 & 0 & 0 & 0 & 0 & 0 & 0 & 11 & 99 & 8 & 121 & 0 & 4 & 28 & 69 & 15 & 9 & 364 \\
\hline X. germanus & 0 & 0 & 0 & 0 & 0 & 0 & 0 & 0 & 0 & 0 & 0 & 32 & 225 & 25 & 450 & 10 & 38 & 263 & 162 & 185 & 76 & 1466 \\
\hline$\Sigma$ & 172 & 7 & 0 & 183 & 578 & 1 & 0 & 0 & 2637 & 447 & 1765 & 1154 & 1283 & 620 & 2751 & 919 & 1381 & 2115 & 1524 & 860 & 415 & 18812 \\
\hline $\max \left(\left(^{\circ} \mathrm{C}\right)\right.$ & 10,8 & 3,8 & 2,1 & 8,9 & 11,8 & 4,5 & 1,4 & 3,4 & 15,6 & 13,3 & 19 & 22,6 & 23,1 & 18,7 & 24,7 & 18,3 & 21,1 & 24 & 26,6 & 26,4 & 27,5 & \\
\hline $\min \left({ }^{\circ} \mathrm{C}\right)$ & $-0,2$ & $-2,9$ & $-3,3$ & $-5,8$ & $-3,9$ & 0,1 & $-7,3$ & $-3,6$ & $-4,5$ & 2,6 & $-0,2$ & 1,3 & 2,8 & 0,9 & 2 & 8,9 & 0,8 & 6,2 & 8,5 & 9,3 & 12,9 & \\
\hline
\end{tabular}

Domowit-Trypowit D’ (Table 2.). Because of period when panel traps were exposed it is not surprising that T. signatum was dominant species, and early ambrosia beetle T. domesticum showed small numbers because it's swarming period was at its end. In year 2010 same attractive components were tested in integrated oak timber protection ETOH, GLV and Domowit-Trypowit $\mathrm{D}^{\circ}$ (Table 3.).

More specimens of X. germanus were caught in year 2010. than in year 2009. because of period when traps were exposed. Panel traps in 2011 and captured first swarming of X. germanus (Table 4.). In 2016, Xylosandrus germanus was trapped in a monitoring program administrated by the Swedish Board of Agriculture (Björklund \& Boberg 2017). There are evidences and proofs how beetle can be easily transmitted and established by various means of spread even in the northern parts of Europe. The likelihood of entry of Xylosandrus germanus into Sweden is assessed to be very likely. Species have already been trapped at two different occasions in Sweden. The main pathways are "Wood and wood products" and "Natural spread". Spread to Sweden has increased since X. germanus recently established in Denmark. Also the likelihood of establishment is assessed to be very likely since suitable host are widely distributed, the climate is suitable and the species have a track record of being able to establish in different environments. If established, the rate of spread is assessed to be high based on the species high flight capacity and the high likelihood of spread through transportation of colonized material (Björklund \& Boberg 2017).

\section{CONCLUSIONS}

\section{ZAKLJUČCI}

$X$. germanus is invasive species that is now present in Croatian lowland oak stands near Zagreb. Its presence in our oak stands is confirmed with our panel trap catches in years 2009, 2010. and 2011. but also from findings in oak timber that was used in part of our experiment in integrated round oak timber protection (Franjevic et_al 2016). Absence from our lineatin baited panel traps can be explained for reason of early trap deployment because our data show that first swarming of $X$. germanus in our oak stands starts from beginning of April, and reason for lack of $X$. germanus catches can be explained in two in two ways. It is possible that $X$. germanus was not yet present in our lowland oak stands near Zagreb, or it had low level population that was not registered by panel trap catches. It is also possible that period of trap deployment was early to register swarming of X. germanus that usually begins in first weeks of April (Peer \& Taborsky 2005). Ethanol is one of most attractive stress-related volatile to X. germanus (C. M. Ranger et al. 2010), so it is open for further experiments to conclude attractivnes of 
Domowit-Trypowit $\mathrm{D}^{\circ}$ to $X$. germanus. Although economic impact is small and fact that the species have been established in Europe for 65 years with few reports of economic impact. In 1995 X. germanus colonized $20000 \mathrm{~m}^{3}$ of round timber of Norway spruce and fir in the Swiss Central Plateau and in the Jura-region (Graf and Manser 2000). From an environmental point of view the main concern is that $X$. germanus have become one of the most abundant scolytids in several areas where it has established (Graf and Manser 2000). But, there are no reports that it has caused any local extinction of native species. Although Xylosandrus germanus is considered to have the potential to have a negative impact on the diversity of scolytid communities (Henin and Versteirt 2004; Bouget and Noblecourt 2005). This is supported by a study in Belgium indicating that $X$. germanus had a niche overlap with several native species (Henin and Versteirt 2004). Never the less build up in population of $X$. germanus leads to some conclusions about stress of host trees in our lowland forests. In North America, X. germanus is one of the economically most important ambrosia beetles in nurseries (Ranger et al. 2010; USDA 2011). Some authors conclude that trees experiencing a certain degree of physiological stress may appear to be healthy but still emit stressrelated volatiles signalling their quality to host-seeking ambrosia beetles (e.g. Kuhnholz et al. 2001). Although X. germanus is considered as pest that attacks physiologicallystressed hosts (Hoffman, 1941; Maksymov, 1987; Bruge, 1995), a few studies have indicated that apparently-healthy trees are also colonized (Weber, 1982; Gregoire et al., 2001). Abundance of X. germanus yet has to be established for the rest of Croatia since it is a polyphagous pest that can develop in our deciduous and conifer forests. X. germanus may also act as a vector for pathogenic fungi and the beetle has mainly been associated with different Fusarium spp. that may cause dieback, wilting and cankers on affected trees. This association has been observed in for example walnut Juglans spp.; (e.g. Frigimelica et al. 1999; Kessler 1974). Although not considered an important vector (Björklund \& Boberg 2017)., $X$. germanus has also been shown to be able to transmit the Dutch Elm disease (Buchanan 1940). Field findings in Croatia after 2009. range from fir in mountainous region to maple in lowlands Further studies should investigate the influence in our young oak stands.

\section{ACKNOWLEDGEMENTS ZAHVALA}

We thank Croatian forest institute Jastrebarsko for the data collected from weather station Spectrum Technologies Inc. Watchdog Weather Station 2000 Series. Forest department Jastrebarsko for providing materials and manpower necessary for this research. Also we thank the anonymous reviewers for useful comments.

\section{REFERENCES}

\section{LITERATURA}

- Bouget, C., and Noblecourt, T. (2005). Short-term development of ambrosia and bark beetle assemblages following a windstorm in French broadleaved temperate forests. Journal of applied entomology, 129(6), 300-310.

- Bruge, H. 1995: Xylosandrus germanus (Blandford, 1894) [Belg. Sp. nov.] (Coleoptera Scolytidae). Bulletin et Annales de la Societe Royale Belge d'Entomologie, 131, 249-264.

- Björklund, Niklas \& Boberg, Johanna. (2017). Rapid Pest Risk Analysis Xylosandrus germanus.

- Buchanan, W.D (1940) Ambrosia beetle Xylosandrus germanus transmits Dutch elm disease under controlled conditions. Journal of Economic Entomology, 33:819-820.

- Czokajlo, D., B. Hrašovec, M. Pernek, J. Hilszczanski, A.Kolk, S.Teale, J. Wickham, P. Kirsch, 2002: New Lure for the Larger Pine Shoot Beetle, Tomicus piniperda - Attractant/Trap Design Combinations Tested in North America and Europe. Proceedings: Ecology, Survey and Management of Forest Insects.

- EN 1316-1: 2012: 2012 (E): Hardwood Round Timber - Qualitative Classification Part 1: Oak and Beech. (CSN EN 1316-1: Hardwood round timber - Qualitative classification - Part 1: Oak and beech. Final draft, 9 p.

- Franjević, Milivoj; Poršinsky, Tomislav; Đuka, Andreja Integrated Oak Timber Protection from Ambrosia Bark Beetles: Economic and Ecological Importance in Harvesting Operations // Croatian journal of forest engineering, 37 (2016), 2; 353-364

- Frigimelica, G., Stergulc, F., Zandigiacomo, P., Faccoli, M., and Battisti, A. (1999). Xylosandrus germanus and walnut disease: an association new to Europe. In Proceedings of the second workshop of the IUFRO working party (Vol. 7, No. 10, pp. 98101). Web page http://www.wsl.ch/dienstleistungen/publikationen/pdf/3484.pdf

- Gauss, R. 1960: Ist Xylosandrus germunus Blandf. ein Primärschädling? Anzeiger für Schädlingskunde, 1960, 9, Pages 168172.

- Graf, E., and Manser, P. (2000). The imported Japanese scolytid beetle Xylosandrus germanus: Biology and damage potential for stored round timber compared to Xyloterus lineatus and Hylecoetus dermestoides. Schweizerische Zeitschrift fur Forstwesen, 151(8), 271-281.

- Gregoire, J.-C., Piel, F., De Proft, M. \& Gilbert, M. 2001: Spatial distribution of ambrosia-beetle catches: a possibly useful knowledgeto improve mass-trapping. Integrated Pest Management Reviews, 6, 237-242.

- Henin JM, Versteirt (2004) Abundance and distribution of Xylosandrus germanus (Blandford 1894) (Coleoptera, Scolytidae) in Belgium: new observations and an attempt to outline its range. Journal of Pest Science 77, 57-63.

- Jendrijev, Đ. 2005: Istraživanje pojave i dinamike populacije hrastovih potkornjaka drvaša

- (Trypodendron spp, Xyleborus spp.) na području đurđevačkih nizinskih šuma. Magistarski rad.

- Hoffman, C.H. 1941: Biological observations on Xylosandrus germanus (Bldfd.). Journal of Economic Entomology, 34, 38-42.

- Kessler Jr, K. J. (1974). An apparent symbiosis between Fusarium fungi and ambrosia beetles causes canker on black walnut stems. Plant Dis. Rep, 58, 1044-1047.

- Kuhnholz, S., Borden, J.H. \& Uzunovic, A. 2001: Secondary ambrosia beetles in apparently healthy trees: Adaptations, potential 
causes and suggested research. Integrated Pest Management Reviews, 6, 209-219.

- MacConell, J. G., J.A. Borden, R.M. Silverstein, E. Stokkink, 1977: Isolation and tenative identification of lineatin, a pheromone from the frass of Trypodendron lineatum (Coleoptera:Scolytidae). J. Chem. Ecol. 3(5): 549-561.

- Maksymov, J.K. 1987: Erstmaliger massenbefall des schwarzen nutzholzborkenkafers, Xylosandrus germanus Blandf., in der Schweiz. Schweizerische Zeitschrift fur Forstwesen, 138, 215-227.

- Moeck, H.A. 1970: Ethanol as the primary attractant fot the ambrosia beetle Trypodendron lineatum (Coleoptera:Scolytidae). Canadian Entomologist, 102, 985-994.

- Peer, K., M. Taborsky, 2005: Outbreeding depression, but no inbreeding depression in haplodiploid ambrosia beetles with regular siblings mating. Evolution, 59(2), 2005, pp. 317-323.
- Petercord, R. 2006: Flight period of the broad-leaved Ambrosia beetle Trypodendron domesticum L. in Luxembourg and Rhineland-Palatinate between 2002 and 2005. IUFRO Working Party 7.03.10 Proceedings of the Workshop 2006, Gmunden/ Austria.

- Ranger, C.M., Reding, M.E, Persad, A.B. \& Herms, D.A. 2010: Ability of stress-related volatiles to attract and induce attacks by Xylosandrus germanus and other ambrosia beetles. Agricultural and Forest Entomology (2010), 12, 177-185

- Schwenke, W. 1974: Die Forstschädlinge Europas. 2. Käfer. Hamburg:Paul Parey Verlag.

- Weber, B.C. 1982: The biology of the ambrosia beetle Xylosandrus germanus (Blandford) (Coleoptera: Scolytidae) and its effects on black walnut. PhD Dissertation, Southern Illinois University.

\section{SAŽETAK}

U prvom desetljeću 21. stoljeća u hrvatskim nizinskim hrastovim sastojinama proveden je niz istraživanja vezanih uz integriranu zaštitu hrastove oblovine. U središtu ovih istraživanja bila je olfaktorna manipulacija domaćim vrstama iz rodova Trypodendron i Xyleborus uz uporabu naletno-barijernih klopki kompletiranih s atraktantima (lineatin, ETOH, GLV, Domowit-Trypowit D'). Tijekom ovih eksperimenata u ulovima naletno-barijernih klopi, pojavila se nova vrsta za hrastove nizinske sastojine u Hrvatskoj Xylosandrus germanus. Pojava vrste Xylosandrus germanus u ulovima naletno barijernih klopki prvi puta je zabilježena u dijelu terenskih eksperimenta (2009. godine), a ulovi u naletno-barijernim klopkamasu bili su u porastu ostatak perioda provedenih istraživanja. Tijekom 2011. godine fenologija potkornjaka drvaša nizinskih hrastovih sastojina provedena je od siječnja do početka lipnja. U ovom periodu zabilježena je i praćena fenologija šest vrsta potkornjaka drvaša, od kojih je T. signatum bio najbrojniji, a invazivna strana vrsta X. germanus je bio drugi po brojnosti tijekom ovog opažanja, iako prisutan u ulovima naletno barijernih klopki 2011 godine. Iako je ekonomski značaj X. germanus malen, ovo je vrsta koja je prisutna u Europi 65 godina. Postoje zabilježeni slučajevi iz Švicarske 1995. g. kada je X. germanus napao $20000 \mathrm{~m}^{3}$ smreke i jele u regiji Jura. S ekološkog gledišta, glavna zabrinutost je da X. germanus postaje jedan od najbrojnijih potkornjaka na područjima u kojima se etablirao, ali bez dokaza o negativnom utjecaju na autohtone vrste. Iako se smatra da X. germanus ima potencijal negativno utjecati na lokalno nestajanje autohtonih vrsta i biološku raznolikost (Henin and Versteirt 2004; Bouget and Noblecourt 2005). Istraživanja u Belgiji pokazuju da postoji preklapanje ekoloških niša X. germanus sa nekoliko autohtonih vrsta (Henin and Versteirt 2004). U Sjevernoj Americi, X. germanus je jedan od ekonomski najvažnijih negativnih čimbenika u rasadnicima. Neki autori navode da postoji izvjesna razina fiziološkog stresa koja nije uočljiva, ali stabla ipak emitiraju stresom generirane atraktivne tvari koje privlače potkornjake tijekom rojenja. X. germanus se smatra štetnikom koji napada fiziološki oslabljena stabla pod stresom, ali neka istraživanja pokazuju da napada i naizgled zdrava stabla. Prisutnost i brojnost X. germanus u Hrvatskoj još treba biti dodatno istražena, jer se ovaj polifagni štetnik uspješno razvija na velikom broju vrsta listača i četinjača. X. germanus isto može biti i vektor za određene uzročnike bolesti i najčešće se povezuje sa gljivama iz roda Fusarium, koje mogu uzrokovati odumiranje stabala, venuće i rak na napadnutim stablima. Ovakav vektorski odnos dokazan je na vrstama iz roda Juglans. X. germanus može prenositi i holandsku bolest brijesta. Zbog navedenog potrebno je daljnje praćenje i istraživanje utjecaja izrazito polifagne invazivne vrste potkornjak drvaša X. germanus na ekosustave nizinskih hrastovih sastojina.

KEY WORDS: potkornjaci drvaši, integrirana zaštita hrastove oblovine, CEN EN 1316-1, FSC, invazivna strana vrsta 